\title{
Teen perception of texting and driving in rural West Virginia
}

Daniel Scott Kahn ${ }^{1}$

Frank Fofie ${ }^{1}$

Grant Buchanan, $\mathrm{MD}^{2}$

Zain Qazi MD ${ }^{2}$

Timothy Wilson-Byrne MD ${ }^{2}$

Tracy LeGrow PsyD ${ }^{3}$

Franklin D. Shuler MD, $\mathrm{PhD}^{2}$

\section{Author Affiliations:}

1. Joan C. Edwards School of Medicine, Marshall University

2. Department of Orthopaedic Surgery, Joan C. Edwards School of Medicine, Marshall University

3. Department of Psychiatry and Behavioral Medicine, Joan C. Edwards School of Medicine, Marshall University

This project was funded by the Robert C. Byrd Center for Rural Health. This work has not been presented at any meetings

Authors have no conflicts of interest to disclose.

\section{Corresponding Author:}

Grant Buchanan, MD

Research Fellow

Department of Orthopaedic Surgery

Joan C. Edwards School of Medicine

Marshall University

Huntington, West Virginia

Email: grantbuchanan2@gmail.com 


\section{Introduction}

In the last decade, texting and driving has evolved into a serious problem among the adolescent population. Motor vehicle crashes are now the number one cause of fatality for teenagers. $^{1-3}$ In 2013 alone, there were over 2000 deaths and nearly 250,000 injuries to teens aged 16-19 from motor vehicle accidents. ${ }^{2}$ Approximately half of these accidents were the result of distracted driving, with text messaging being a major source of distraction..$^{1-4}$ Research has shown that $94 \%$ of teens acknowledge that texting and driving is dangerous, yet over $1 / 3$ continue to text and drive. ${ }^{1,5}$ As of 2015,47 states have instituted laws banning texting and driving; despite these changes, teens continue to text and drive. ${ }^{1-3,5,6}$ Considering the potentially devastating impact of texting and driving, additional steps must be taken to reduce this behavior among the adolescent population.

The goal of this study was to determine if education could effectively raise awareness of the dangers of texting and driving and positively influence the behavior of rural West Virginia teens. The authors hypothesized that although teens are aware of the dangers of texting and driving, they continue to engage in this risky behavior, and that education would significantly improve awareness of the dangers of texting and driving and reduce the number of teens who exhibit this behavior.

\section{Methods}

This study received IRB approval and informed consent and assent was obtained from all subjects and their parents, as many participants were minors. Five rural West Virginia high schools in Logan, Lincoln, and Wayne counties participated in the study. Senior students were administered a 20 question survey to assess their driving behavior (Table 1). After completing the survey, students received a 20-minute lecture explaining how texting and driving can impair driving ability and showing graphic images of accidents resulting from texting and driving. After three months, students were emailed the same survey to determine whether their driving behavior had changed. Pre and post-lecture responses were compiled in Microsoft Excel ${ }^{\circledR}$. Statistical analysis involved a Z-score test for two proportions, which was performed using Stata 13.0 (College Station, TX). 
Figure 1. Survey administered to students to assess driving behavior.

\begin{tabular}{|c|c|c|c|c|c|c|c|c|c|}
\hline What is your gender? & \multicolumn{4}{|c|}{ Male } & \multicolumn{5}{|c|}{ Female } \\
\hline \multicolumn{10}{|l|}{ How old are you? } \\
\hline $\begin{array}{l}\text { Have you completed } \\
\text { driver's education? }\end{array}$ & \multicolumn{4}{|c|}{ Yes } & \multicolumn{5}{|c|}{ No } \\
\hline $\begin{array}{c}\text { Do you have a learner's } \\
\text { permit or license? }\end{array}$ & \multicolumn{2}{|c|}{ License } & \multicolumn{4}{|c|}{ Permit } & \multicolumn{3}{|c|}{ Neither } \\
\hline $\begin{array}{l}\text { How long have you } \\
\text { been driving? }\end{array}$ & $\begin{array}{r}\text { Not } \\
\text { drivin }\end{array}$ & \multicolumn{2}{|c|}{$<1$ year } & $1-2$ & ears & \multicolumn{3}{|c|}{$2-3$ years } & $>3$ years \\
\hline $\begin{array}{c}\text { Do you have your own } \\
\text { car? }\end{array}$ & \multicolumn{4}{|c|}{ Yes } & \multicolumn{5}{|c|}{ No } \\
\hline $\begin{array}{l}\text { How dangerous do you } \\
\text { think texting and } \\
\text { driving is? }\end{array}$ & \multicolumn{2}{|c|}{ Not at all } & \multicolumn{2}{|l|}{ Mildly } & \multicolumn{3}{|c|}{ Moderately } & & Very \\
\hline $\begin{array}{l}\text { How concerned are you } \\
\text { about having a serious } \\
\text { accident while texting } \\
\text { and driving? }\end{array}$ & \multicolumn{2}{|c|}{ Not at all } & \multicolumn{2}{|l|}{ Mildly } & \multicolumn{3}{|c|}{ Moderately } & \multicolumn{2}{|r|}{ Very } \\
\hline $\begin{array}{l}\text { In the past week, how } \\
\text { many miles have you } \\
\text { driven per day? }\end{array}$ & 0 & $1-10$ & \multicolumn{2}{|c|}{$11-20$} & \multicolumn{2}{|c|}{$21-30$} & \multicolumn{2}{|c|}{$31-40$} & $>40$ \\
\hline $\begin{array}{l}\text { In the past week, how } \\
\text { many times have you } \\
\text { texted while driving? }\end{array}$ & 0 & $1-10$ & \multicolumn{2}{|c|}{$11-20$} & \multicolumn{2}{|c|}{$21-30$} & \multicolumn{2}{|c|}{$31-40$} & $>40$ \\
\hline $\begin{array}{l}\text { In the past week, how } \\
\text { many texts have you } \\
\text { read while driving? }\end{array}$ & 0 & $1-10$ & \multicolumn{2}{|c|}{$11-20$} & \multicolumn{2}{|c|}{$21-30$} & \multicolumn{2}{|c|}{$31-40$} & $>40$ \\
\hline $\begin{array}{l}\text { In the past week, how } \\
\text { many texts have you } \\
\text { responded to while } \\
\text { driving? }\end{array}$ & 0 & $1-10$ & \multicolumn{2}{|c|}{$11-20$} & \multicolumn{2}{|c|}{$21-30$} & \multicolumn{2}{|c|}{$31-40$} & $>40$ \\
\hline $\begin{array}{l}\text { In the past week, how } \\
\text { many phone calls have } \\
\text { you answered while } \\
\text { driving? }\end{array}$ & 0 & $1-10$ & $11-2$ & & 21 & 30 & & -40 & $>40$ \\
\hline $\begin{array}{l}\text { In the past week, how } \\
\text { many phone calls have } \\
\text { you made while } \\
\text { driving? }\end{array}$ & 0 & $1-10$ & $11-2$ & & 21 & 30 & & -40 & $>40$ \\
\hline $\begin{array}{l}\text { In the past week, how } \\
\text { many times have you } \\
\text { ridden with drivers who } \\
\text { text? }\end{array}$ & 0 & $1-10$ & $11-2$ & & 21 & 30 & & -40 & $>40$ \\
\hline $\begin{array}{l}\text { What types of things do } \\
\text { you text about? }\end{array}$ & $\begin{array}{l}\text { Future } \\
\text { plans }\end{array}$ & $\begin{array}{l}\text { Status } \\
\text { updates }\end{array}$ & $\begin{array}{c}\text { Chatt } \\
\text { ing }\end{array}$ & & & Twi & & $\begin{array}{l}\text { Snap } \\
\text { chat }\end{array}$ & $\begin{array}{l}\text { Face- } \\
\text { book }\end{array}$ \\
\hline
\end{tabular}




\begin{tabular}{|c|c|c|c|c|}
\hline $\begin{array}{l}\text { Is texting and driving } \\
\text { legal is you are older } \\
\text { than } 18 ?\end{array}$ & \multicolumn{2}{|c|}{ Yes } & \multicolumn{2}{|c|}{ No } \\
\hline $\begin{array}{l}\text { Is texting and driving } \\
\text { legal in West Virginia? }\end{array}$ & \multicolumn{2}{|c|}{ Yes } & \multicolumn{2}{|c|}{ No } \\
\hline $\begin{array}{l}\text { Compared to alcohol, } \\
\text { how does texting affect } \\
\text { your driving ability? }\end{array}$ & Hinders less & \multicolumn{2}{|c|}{ Hinders the same } & Hinders more \\
\hline $\begin{array}{l}\text { Have you ever come } \\
\text { close to having an } \\
\text { accident because you } \\
\text { were texting or talking } \\
\text { on the phone? }\end{array}$ & \multicolumn{2}{|c|}{ Yes } & \multicolumn{2}{|c|}{ No } \\
\hline $\begin{array}{c}\text { How often do you wear } \\
\text { a seatbelt? }\end{array}$ & Always & $\begin{array}{l}\text { Most of the } \\
\text { time }\end{array}$ & Sometimes & Never \\
\hline $\begin{array}{c}\text { In the past month, how } \\
\text { many times have you } \\
\text { drank alcohol and } \\
\text { driven? }\end{array}$ & 0 & $1-5$ & $5-10$ & $>10$ \\
\hline $\begin{array}{l}\text { How many people do } \\
\text { you know who have had } \\
\text { a bad car accident? }\end{array}$ & 0 & $1-5$ & $5-10$ & $>10$ \\
\hline $\begin{array}{l}\text { How many people do } \\
\text { you know who have had } \\
\text { a bad car accident } \\
\text { because of texting? }\end{array}$ & 0 & $1-5$ & $5-10$ & $>10$ \\
\hline $\begin{array}{c}\text { Do you know anyone } \\
\text { who was killed in a car } \\
\text { accident? }\end{array}$ & \multicolumn{2}{|c|}{ Yes } & \multicolumn{2}{|c|}{ No } \\
\hline
\end{tabular}

\section{Results}

A total of 143 students completed the pre-lecture survey, and 74 completed the post-lecture survey. Among the pre-lecture participants, the average age was 17.8 years; $52 \%$ were male and $48 \%$ were female. Approximately $64 \%$ possessed a driver's license, $26 \%$ had learner's permits, and $10 \%$ had neither. When asked how long they had been driving, $43 \%$ had been driving less than a year, $14 \%$ between $1-2$ years, $33 \%$ between $2-3$ years, and $10 \%$ between 3-4 years. Of those who drove, $63 \%$ had access to their own car.

Approximately $57 \%$ of students admitted to either reading or sending text messages while driving in the past week, and $88 \%$ had ridden with a driver who texted. Approximately $73 \%$ of students believed that texting and driving was 'very' dangerous. Around 19\% of students admitted that they had come close to having an accident because they were texting or talking on the phone while driving. Furthermore, 59\% admitted to talking on the phone (both placed and answered) while driving in the past week. Around $11 \%$ admitted to drinking and driving within the past month, and $32 \%$ had ridden with a driver who had been drinking. The majority of students (62\%) knew someone who had been killed in a car accident, and $36 \%$ knew someone who had been in an accident because of texting. Lastly, $27 \%$ of students believed texting and driving to be legal after 18 . 
When pre and post-lecture survey responses were compared, there were no statistically significant differences $(p<0.05)$ in the teens' perception of the danger of texting and driving, how concerned they were about being in an accident while texting and driving, how often they text while driving, and how many phone calls they make while driving (Table 1).

Table 1. Comparison of pre-test and post-test survey responses.

\begin{tabular}{|c|c|c|c|c|}
\hline & $\begin{array}{c}\text { Pre-test } \\
(\mathrm{n}=143)\end{array}$ & $\begin{array}{c}\text { Post-test } \\
(\mathrm{n}=74)\end{array}$ & Z-score & p-value \\
\hline $\begin{array}{c}\text { Proportion that } \\
\text { perceived texting and } \\
\text { driving to be 'very' } \\
\text { dangerous }\end{array}$ & $73 \%$ & $84 \%$ & -1.72 & 0.086 \\
\hline $\begin{array}{c}\text { Proportion that were } \\
\text { 'very' concerned about } \\
\text { having an accident } \\
\text { while texting and } \\
\text { driving }\end{array}$ & $51 \%$ & $62 \%$ & -1.51 & 0.132 \\
\hline $\begin{array}{c}\text { Proportion admitting } \\
\text { to texting and driving }\end{array}$ & $57 \%$ & $53 \%$ & 0.55 & 0.580 \\
\hline $\begin{array}{c}\text { Proportion admitting } \\
\text { to talking on the phone } \\
\text { while driving }\end{array}$ & $59 \%$ & $54 \%$ & 0.66 & 0.508 \\
\hline
\end{tabular}

\section{Discussion}

Although the educational session failed to alter teenage driving behavior in a statistically significant manner, the results reveal that distracted driving is highly prevalent among rural West Virginia teens. Nearly half of teens admitted to reading and responding to text messages while driving. Additionally, 59\% made phone calls while driving; using a hand-held phone while driving also constitutes distracted driving and is illegal for novice drivers in 37 states including West Virginia. Another alarming finding was that $11 \%$ of teens admitted to drinking and driving. Teens exhibited these behaviors despite the majority (73\%) acknowledging that texting and driving is very dangerous.

Prior research has shown that young drivers possess a false sense of confidence in their driving skills, claiming that they feel comfortable texting and driving without fear of causing an accident. ${ }^{1}$ However, teens who text and drive are 23 times more likely to have an accident than their non-distracted counterparts. ${ }^{1}$ It has even been found that texting can be more disruptive than driving under the influence of alcohol and cannabis. ${ }^{7,8}$ Studies have shown a delayed reaction time and lateral position deviation during the act of texting while operating a vehicle. ${ }^{7,8}$ It should come as no surprise that impairing a driver's visual, mental, and physical capacity, regardless of speed, leads to more accidents. ${ }^{1,4,5,7}$

Adolescents' false sense of self-assurance, tendency towards riskier behavior, lack of experience, and inability to multitask increases their probability of an accident. ${ }^{9-12}$ There is evidence that drivers who participate in drivers' education demonstrate safer driving habits during their first year driving before declining after 18 months. ${ }^{11,12}$ Also, teens that make 
more conscientious decisions tend to have lower accident rates. ${ }^{11,12}$ It is imperative that the adolescent population is challenged to be more conscientious and practice safer driving habits.

This study failed to observe an improvement in teen driving behavior after an educational session. The failure to alter driving behavior may be largely due to the fact that teens already acknowledged that texting and driving was dangerous and continued to engage regardless. Perhaps other methods would be more effective at reducing texting while driving.

A number of cell phone applications have been developed to help combat distracted driving. ${ }^{13-16}$ These applications are capable of disabling text messaging functions when a vehicle is in motion, and some will notify parents when a teen attempts to use their phone while driving. This technology shows promise in reducing distracted driving. However, these applications often require the initiative of a parent to install and monitor the system as well as pay a subscription fee, which may pose a barrier. Many parents may be uninterested in installing such an application because they also text and drive, as this behavior is not limited to adolescents.

The ability of this study to measure a change in teen behavior was severely limited by a high rate of attrition, with only $52 \%$ completing the post-lecture survey. Furthermore, a single 20 minute lecture may have been insufficient to effect a lasting change in adolescent behavior. More research is needed to establish an effective strategy to reduce texting and driving.

\section{Conclusion}

This study revealed that texting and driving is highly prevalent among rural West Virginia teens, with $57 \%$ of teens admitting to exhibiting this behavior. Around $73 \%$ of teens agreed that texting and driving was very dangerous, but many continued to do so regardless.

Additionally, 59\% admitted to talking on the phone while driving, and $11 \%$ admitted to drinking and driving. This study failed to observe any effect of a single lecture at reducing texting and driving behavior among the study population; there was no statistically significant increase in the proportion of teens that thought texting and driving was very dangerous $(\mathrm{p}=0.086)$, and there was no statistically significant decrease in the proportion of teens who admitted to texting and driving $(\mathrm{p}=0.580)$. More research is needed to establish an effective way to reduce this dangerous behavior. 


\section{References}

1. Megan A, Moreno M. Texting and driving. JAMA Pediatrics.168(12).

2. CDC. Web-based injury statistics query and reporting system (WISQARS) [Online]. 2013.

3. CDC. Distracted driving in the United States and Europe. Centers for Disease Control and Prevention. 2012; June.

4. Megan A, Moreno M. Distracted driving and motor vehicle crashes among teens. JAMA Pediatrics.167(10).

5. Carney C, Harland H, Weiss M, Raby M. Using naturalistic driving data to assess the prevalence of environment factors and driver behaviors in teen driver crashes. AAA Foundation for Traffic Safety. 2015; March.

6. Ferdinand AO, Menachemi N, Sen B, Blackburn JL, Morrisey M, Nelson L. Impact of texting laws on motor vehicular fatalities in the United States. Am J Public Health. 2014;104(8):1370-7.

7. Sexton BF, Tunbridge RJ, Board A, Jackson PG,Wright K, Stark MM, Englehart K. The influence of cannabis and alcohol on driving. Crowthorne, England: 2002.

8. Reed N, Robbins R. The effect of text messaging on driver behaviour: a simulator study. Transport research Laboratory. 2008; 367: 1-54.

9. Williams AF. Teenage drivers: patterns of risk. Journal of safety research. 2003;34(1):5-15.

10. Steinberg L. A social neuroscience perspective on adolescent risk-taking. Developmental review. 2008;28(1):78-106.

11. Simons-Morton BG, Klauer SG, Ouimet MC, Guo F, Albert PS, Lee SE, et al. Naturalistic teenage driving study: findings and lessons learned. Journal of safety research. 2015;54:41.e29-44.

12. Ehsani JP, Li K, Simons-Morton BG, Fox Tree-McGrath C, Perlus JG, O'Brien F, et al. Conscientious personality and young drivers' crash risk. Journal of safety research. 2015;54:83.e29-87.

13. Canary. The Canary Project (Internet). 2016 [cited 20 Jan 2016]. Available from: http://www.thecanaryproject.com/

14. Cellcontrol. Technology to stop distracted driving (Internet). 2016 [cited 20 Jan 2016]. Available from: https://www.cellcontrol.com/

15. TextLimit. Distracted driving kills (Internet). 2016 [cited 20 Jan 2016]. Available from: https://textlimit.com/

16. DriveSafe.ly. The app to stop distracted driving (Internet). 2016 [cited 20 Jan 2016]. Available from: http://www.drivesafe.ly! 